\title{
PENGARUH MANAJEMEN LABA DAN PERBEDAAN PEMBUKUAN MENURUT PAJAK DAN AKUNTANSI TERHADAP PERINGKAT OBLIGASI
}

\author{
Cerelia Chandra dan Hanna \\ Alumni Fakultas Ekonomi Universitas Pelita Harapan \\ Email: cerelia_chandra@hotmail.comdan hanna.wijaya@uph.edu
}

\begin{abstract}
This study aimed to test the effect of earnings management and book-tax differences to the bond ratings. The sample in this study are gathered by using purposive sampling from all companies that listed on the Indonesian Stock Exchange and issued bonds in a row from January 2010 to June 2013. The Company elected as sample amounted to 13 companies or as many as 182 of observation data. In this study, we used multiple linear regression method. The results showed that earnings management does not have a significant effect on bond ratings. While book-tax difference has a positive and significant effect on bond ratings.
\end{abstract}

Keywords: earnings management, book-tax difference, size, current ratio, growth, return on assets, productivity ratio.

\begin{abstract}
Abstrak: Penelitian ini bertujuan untuk menguji apakah manajemen laba dan perbedaan pembukuan menurut pajak dan akuntansi berpengaruh terhadap peringkat obligasi. Pemilihan sampel dalam penelitian ini menggunakan metode purposive samplingdari perusahaan-perusahaan yang go public di BEIdan menerbitkan obligasi secara berturut-turut dari bulan Januari 2010 sampai Juni 2013. Perusahaan yang terpilih menjadi sampel penelitian ini berjumlah 13 perusahaan atau sebanyak 182 data observasi. Dalam penelitian ini digunakan metode regresi linier berganda.Hasil penelitian ini menunjukkan bahwa manajemen laba tidak memiliki pengaruh yang signifikan terhadap peringkat obligasi. Perbedaan pembukuan menurut pajak dan akuntansi (book-tax difference) berpengaruh positif dan signifikan terhadap peringkat obligasi.
\end{abstract}

Kata kunci: earnings management, book-tax difference, size, current ratio, growth, return on assets, rasio produktivitas.

\section{PENDAHULUAN}

Peringkat obligasi adalah penilaian risiko obligasi yang dikeluarkan di Indonesia oleh lembaga pemeringkat yaitu PT Pemeringkat Efek Indonesia (PT PEFINDO). Peringkat obligasi ini digunakan sebagai informasi risiko dari suatu obligasi, sehingga peringkat ini dapat menjelaskan mengenai probabilitas kegagalan pembayaran hutang dan kinerja suatu perusahaan. Peringkat obligasi dapat ditentukan dari hasil laporan keuangan perusahaan. Jika kinerja suatu perusahaan baik, maka obligasi juga akan mempunyai peringkat yang baik, sehingga akan semakin banyak investor yang tertarik pada obligasi tersebut. Salah satu cara agar laporan keuangan terlihat baik adalah dengan melakukan manajemen laba. Manajemenlabamerupakan suatu penyimpangan dalam penyusunan 
laporan keuangan, yaitu mempengaruhi tingkat laba yang ditampilkan dalam laporan keuangan (Herawaty, 2008).

Jika suatu perusahaan terbukti melakukan manajemen laba, maka akan terjadi penilaian peringkat obligasi yang rendah oleh lembaga pemeringkat. Sebaliknya, jika suatu perusahaan tidak terbukti melakukan manajemen laba, maka laporan keuangan yang disajikan telah menggambarkan kondisi perusahaan yang sebenarnya, sehingga informasi kepada para investor pun menjadi akurat. Oleh karena itu, peringkat obligasi dari perusahaan tersebut dapat dinilai tinggi oleh lembaga pemeringkat obligasi.

Salah satu faktor yang digunakan oleh lembaga pemeringkat adalah informasi keuangan yang tersedia. Informasi ini diberikan dalam bentuk laporan keuangan perusahaan. Laporan ini berisi informasi penting yang dapat digunakan untuk menilai kondisi perusahaan (Onji, 2013). Informasi keuntungan atau kerugian yang umumnya digunakan oleh perusahaan adalah laporan laba rugi perusahaan. Namun, dalam suatu periode perusahaan memiliki dua perhitungan, yaitu laba akuntansi dan laba menurut pajak.

Adanya perbedaan perhitungan dan pembukuan menurut akuntansi dan pajak, mengakibatkan adanya selisih perbedaan hasil antara laba akuntansi dan laba menurut pajak yang disebut book-tax differences. Laba akuntansi disusun berdasarkan Pernyataan Standar Akuntansi Keuangan (PSAK) Nomor 25, sedangkan laba pajak dihitung dan disajikan berdasarkan Undang-undang Nomor 36 Tahun 2008 dan PSAK Nomor 46. Laba akuntansi cenderung lebih fleksibel karena menganut accrual basis, sehingga manajemen dapat menyesuaikan pendapatan dan beban yang akan diakui pada laporan keuangan suatu perusahaan. Sedangkan laba menurut pajak dihitung berdasarkan peraturan yang cenderung lebih tegas secara undang-undang dan menganut cash basis.

Menurut Wijayanti (2006), book-tax differences timbul dari perbedaan yang sifatnya sementara (temporary differences) dan sifatnya tetap (permanent differences). Perbedaan yang bersifat sementara, timbul akibat perbedaan metode akuntansi serta saat pengakuan pendapatan dan biaya. Perbedaan ini akan mempengaruhi laba pada periode yang akan datang karena perbedaan temporer ini akan menimbulkan aset pajak tangguhan dan kewajiban pajak tangguhan. Sedangkan perbedaan yang bersifat tetap, timbul karena adanya perbedaan tujuan dan rugi yang dialami perusahaan pada tahun-tahun sebelumnya yang dapat dikompensasikan atas laba tahun berjalan (loss carryback and carryforward). Oleh karena itu, manajemen berkewajiban untuk melakukan penyesuaian atas laba akuntansi berdasarkan ketentuan perpajakan yang berlaku dalam menghitung laba fiskal atau disebut dengan rekonsiliasi fiskal.

Penelitian Sari dan Bandi (2010) yang meneliti pengaruh manajemen laba terhadap peringkat obligasi pada saat emisi menyimpulkan bahwa manajemen laba berpengaruh positif terhadap peringkat obligasi. Penelitian Rani dan Christine (2011) yang meneliti pengaruh perbedaan pembukuan menurut pajak dan akuntansi terhadap perubahan peringkat obligasi menyimpulkan bahwa tidak ada pengaruh yang signifikan antara perbedaan pembukuan menurut pajak dan akuntansi terhadap perubahan peringkat obligasi. Penelitian Christina, Yulianti, dan Christine (2010) yang meneliti pengaruh booktax difference terhadap peringkat obligasi di Indonesia menyimpulkan bahwa perbedaan positif besar antara pembukuan menurut pajak dan akuntansi tidak berpengaruh signifikan terhadap peringkat obligasi, sedangkan perbedaan negatif besar antara pembukuan menurut pajak dan akuntansi berpengaruh signifikan terhadap peringkat obligasi. Penelitian Ayers et. al. (2008) yang meneliti pengaruh book-tax difference terhadap 
peringkat obligasi menyimpulkan bahwa book-tax difference memiliki pengaruh negatif yang signifikan terhadap peringkat obligasi. Dengan adanya perbedaan dari beberapa hasil penelitian mengenai pengaruh perbedaan pembukuan menurut pajak dan akuntansi terhadap peringkat obligasi, maka peneliti tertarik untuk mengujinya kembali. Sementara itu, dengan adanya metode pengukuran manajemen laba yang baru yaitu disretionary revenue, maka peneliti tertarik untuk menguji kembali pengaruh manajemen laba terhadap peringkat obligasi.

Penelitian ini memiliki beberapa keunggulan dibandingkan dengan penelitianpenelitian sebelumnya. Pertama, laporan keuangan dan peringkat obligasi yang digunakan pada penelitian ini yaitu laporan keuangan dan peringkat per tiga bulan (triwulan), sedangkan penelitian sebelumnya hanya menggunakan laporan keuangan tahunan, sehingga peringkat obligasi hanya mencerminkan obligasi satu tahun tersebut tanpa mengetahui peringkat obligasi bulan-bulan sebelumnya apakah peringkat obligasi yang dihasilkan perusahaan stabil atau tidak. Kedua, penelitian ini juga menggunakan pengukuran manajemen laba yang berbeda dibandingkan dengan penelitian-penelitian sebelumnya. Penelitian ini menggunakan discretionary revenue sebagai alat ukur manajemen laba, sedangkan penelitian-penelitian sebelumnya menggunakan modified jones yang merupakan model pengukuran yang menggunakan discretionary accrual, dimana model ini tidak membedakan peningkatan diskresionari pada laba melalui pendapatan atau komponen beban sehingga dapat memberikan bias dalam suatu penelitian (Stubben, 2010). Ketiga, penelitian ini dilakukan pada semua jenis industri perusahaan kecuali di bidang finance,banking, dan insurance dari bulan Januari 2010 sampai Juni 2013 yang terdaftar di Bursa Efek Indonesia (BEI) dan memiliki peringkat obligasi yang telah dinilai oleh PT PEFINDO.

Penelitian ini berusaha untuk menemukan beberapa bukti empirirs untuk menjawab pertanyaan: (1) Apakah terdapat pengaruh manajemen labaterhadap peringkat obligasi? (2) Apakah terdapat pengaruh perbedaan pembukuan menurut pajak dan akuntansiterhadap peringkat obligasi? (3) Apakah manajemen laba dan perbedaan pembukuan menurut pajak dan akuntansi secara bersama-sama mempengaruhi peringkat obligasi?

Hasil dari penelitian ini diharapkan dapat memberikan manfaat baik untuk peneliti sendiri sebagai penambah wawasan, peneliti selanjutnya sebagai referensi, bagi masyarakat dan pelaku bisnis untuk menambah informasi mengenai bagaimana pengaruh manajemen laba dan pengaruh perbedaan pembukuan menurut pajak dan akuntansi terhadap peringkat obligasi, dan pihak-pihak lain yang berkepentingan.

\section{KAJIAN TEORI}

Laba Akuntansi dan Laba Menurut Pajak. Laba akuntansi adalah laba atau rugi bersih dalam suatu periode dikurang beban pajak yang dihitung berdasarkan prinsip akuntansi yang berlaku umum dan digunakan untuk menilai kinerja ekonomi suatu perusahaan (Agoes dan Trisnawati, 2012). Menurut Agoes dan Trisnawati (2012), Laba menurut pajak atau laba fiskal adalah laba atau rugi dalam suatu periode yang dihitung berdasarkan peraturan perpajakan dan digunakan untuk menjadi dasar perhitungan $\mathrm{PPh}$.

Beda Waktu dan Beda Tetap. Book-tax differences merupakan perbedaan jumlah laba yang dihitung berdasarkan akuntansi dengan laba yang dihitung sesuai dengan peraturan 
perpajakan. Perbedaan tersebut menimbulkan dua jenis beda yaitu beda tetap (permanent differences) dan beda waktu (temporary differences). Beda tetap atau perbedaan permanen merupakan item-item yang dimasukkan dalam salah satu ukuran laba, tetapi tidak dimasukkan dalam ukuran laba yang lain. Dengan kata lain, jika suatu item termasuk dalam ukuran laba akuntansi, maka item tersebut tidak dimasukkan dalam ukuran laba fiskal dan sebaliknya (Wijayanti, 2006). Kewajiban pajak tangguhan timbul apabila terdapat koreksi negatif sehingga beban pajak menurut akuntansi lebih besar daripada beban pajak menurut peraturan perpajakan (Agoes dan Trisnawati, 2012).

Perbedaan laba akuntansi dan laba menurut pajak (Book-tax Differences). Menurut Rani dan Christine (2011), setiap tahunnya, perusahaan pada umumnya memiliki dua jenis informasi penghasilan, yaitu: laba menurut akuntansi dan laba menurut pajak. Perbedaan dalam aturan akuntansi dan pajak menyebabkan adanya perbedaan jumlah laba akuntansi dan laba menurut pajak. Laba akuntansi atau laba komersial dihitung sebagai laporan kepada pemegang saham, sementara laba menurut pajak atau laba fiskal dihitung sebagai laporan ke kantor pelayanan pajak. Laba fiskal diperoleh melalui penyesuaian jenis-jenis pendapatan yang dapat diakui sebagai penghasilan dan biaya-biaya yang dapat dibebankan sebagai pengurang penghasilan berdasarkan UU No. 36 Tahun 2008.Pasal 4 ayat 1, mengatur mengenai penghasilan-penghasilan yang dapat diakui sebagai penambah kekayaan WP yang bersangkutan.Pasal 4 ayat 2, mengatur mengenai penghasilanpenghasilan yang dapat dikenai pajak yang bersifat final.Pasal 4 ayat 3 , mengatur mengenai beberapa penghasilan yang tidak dapat diakui sebagai penambah kekayaan WP.

Selain itu dalam UU No. 36 Tahun 2008 juga diatur mengenai biaya-biaya yang dapat diakui dalam penyusunan laporan keuangan (deductible expenses) yang terdapat dalam pasal 6 ayat 1 . Sedangkan pada pasal 9 ayat 1 diatur mengenai biaya-biaya yang tidak dapat diakui dalam penyusunan laporan keuangan (non deductible expenses).

Obligasi. Onji (2013) mendefinisikan obligasi sebagai surat hutang jangka panjang yang dapat dipindah tangankan yang berisi janji dari pihak yang menerbitkan untuk membayar imbalan berupa bunga pada periode tertentu dan melunasi pokok hutang pada jangka waktu yang telah ditentukan kepada pihak pembeli obligasi.Menurut Sunariyah (2004), ada beberapa keuntungan dari obligasi, yaitu (1) Tingkat bunga obligasi bersifat konstan karena tidak dipengaruhi harga di pasar obligasi. (2) Pemegang obligasi mendapatkan pendapatan yang pasti dalam setiap periodenya sesuai dengan perjanjian yang telah dibuat. Jika dibandingkan dengan saham, return saham sangat bervariasi dan return tersebut tergantung pada laba perusahaan. Apabila laba perusahaan turun, maka return yang didapatkan juga akan turun, dan begitu pula sebaliknya.

Peringkat Obligasi.Berdasarkan keputusan Badan Pengawas Pasar Modal dan Lembaga Keuangan (BAPEPAM-LK) Kep-151/BL/2009, peringkat obligasi merupakan opini dari lembaga pemeringkat serta sumber normatif bagi pemodal atas risiko obligasi yang diperdagangkan di pasar modal. Informasi peringkat tersebut diharapkan dapat membantu investor dalam mengambil keputusan investasi.

Menurut Onji (2013), peringkat obligasi bermanfaat untuk mengetahui struktur obligasi dan mengetahui posisi kinerjanya jika dibandingkan dengan perusahaan lain. Jika perusahaan mendapatkan peringkat yang baik, maka peringkat tersebut dapat dimanfaatkan perusahaan sebagai sarana promosi dan meningkatkan kepercayaan investor karena perusahaan memiliki kemampuan untuk membayar obligasi dengan baik. Dengan 
demikian, pemodal yang berinvestasi pada obligasi pada perusahaan tersebut semakin banyak dan sumber dana yang diperoleh juga semakin besar. Peringkat obligasi penting untuk diperhati-kan karena menunjukkan skala risiko atau tingkatkeamanan dari suatu obligasi yang diterbitkan. Lebih lanjut, dinyatakan bahwa peringkat obligasiini penting karena peringkat tersebut memberikanpernyataan yang informatif dan memberikan sinyaltentang probabilitas kegagalan utang suatu perusahaan (Raharja dan Sari, 2008).

Di Indonesia memiliki level peringkat obligasi terdiri dari AAA, AA, A, BBB, BB, B, CCC,D.Tanda plus (+) atau (-) dalam peringkat obligasi PT PEFINDO menunjukkan kemungkinan naik atau turunnya peringkat obligasi di masa yang akan datang, misalnya: obligasi dengan peringkat AA+ berarti peringkat obligasi tersebut akan naik menjadi AAA atau jika peringkat obligasinya AA-, maka ada kemungkinan peringkat obligasi di masa yang akan datang akan turun menjadi A.

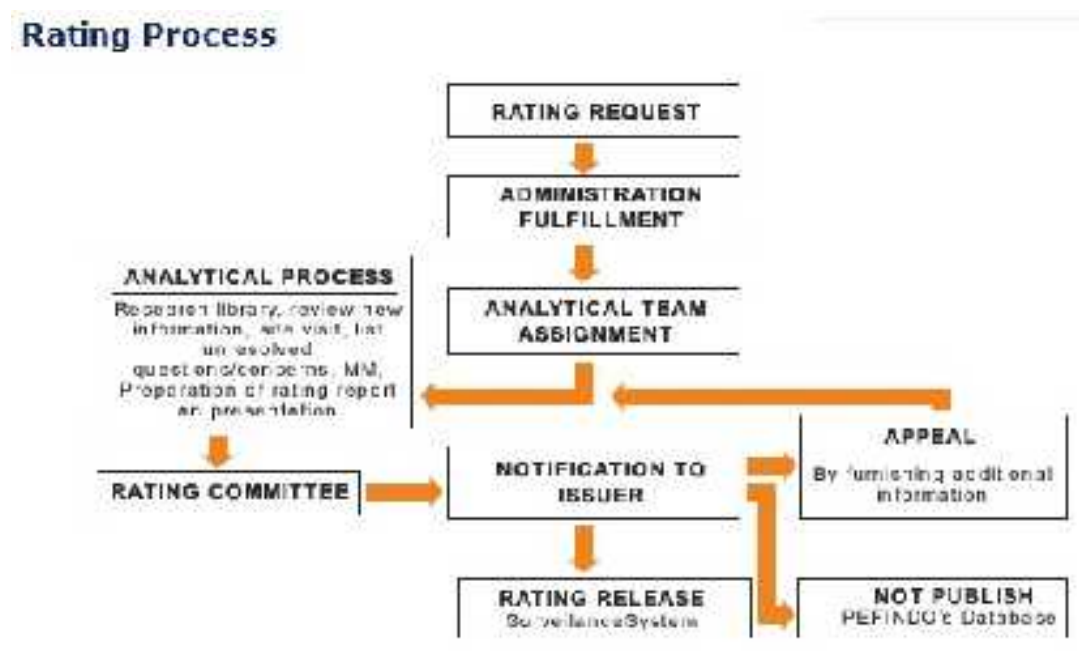

Gambar 1 Proses Rating

Sumber: PT PEFINDO (new.pefindo.com)

Manajemen Laba. Menurut Gumanti (2000) dalam Fahmi (2013), manajemen laba adalah suatu tindakan yang mengatur laba sesuai dengan yang dikehendaki oleh pihak tertentu atau pihak manajemen. Tindakan manajemen laba sebenarnya didasarkan oleh berbagai tujuan dan maksud-maksud tertentu, salah satunya yaitu prestasi manajemen dimana besar kecilnya bonus yang akan diterima oleh manajer tergantung dari besar kecilnya laba yang diperoleh perusahaan.

Menurut Fahmi (2013), tindakan manajemen laba tidak harus diartikan sebagai upaya untuk memanipulasi data, tetapi lebih diartikan sebagai pemilihan metode akuntansi untuk mengatur besarnya keuntungan yang diinginkan. Namun, karena tindakan tersebut dilandasi oleh tujuan-tujuan tertentu, maka laporan keuangan harus tetap diperiksa untuk mencegah adanya informasi keuangan yang tidak akurat bagi para investor.

Fisher dan Rosenzweig dalam Sulistyanto (2008), menyebutkan bahwa manajemen laba adalah tindakan-tindakan manajer untuk menaikkan (menurunkan) laba periode berjalan dari sebuah perusahaan yang dikelolanya tanpa menyebabkan kenaikan (penurunan) keuntungan ekonomi perusahaan jangka panjang. 
Tabel 1. Penelitian Terdahulu

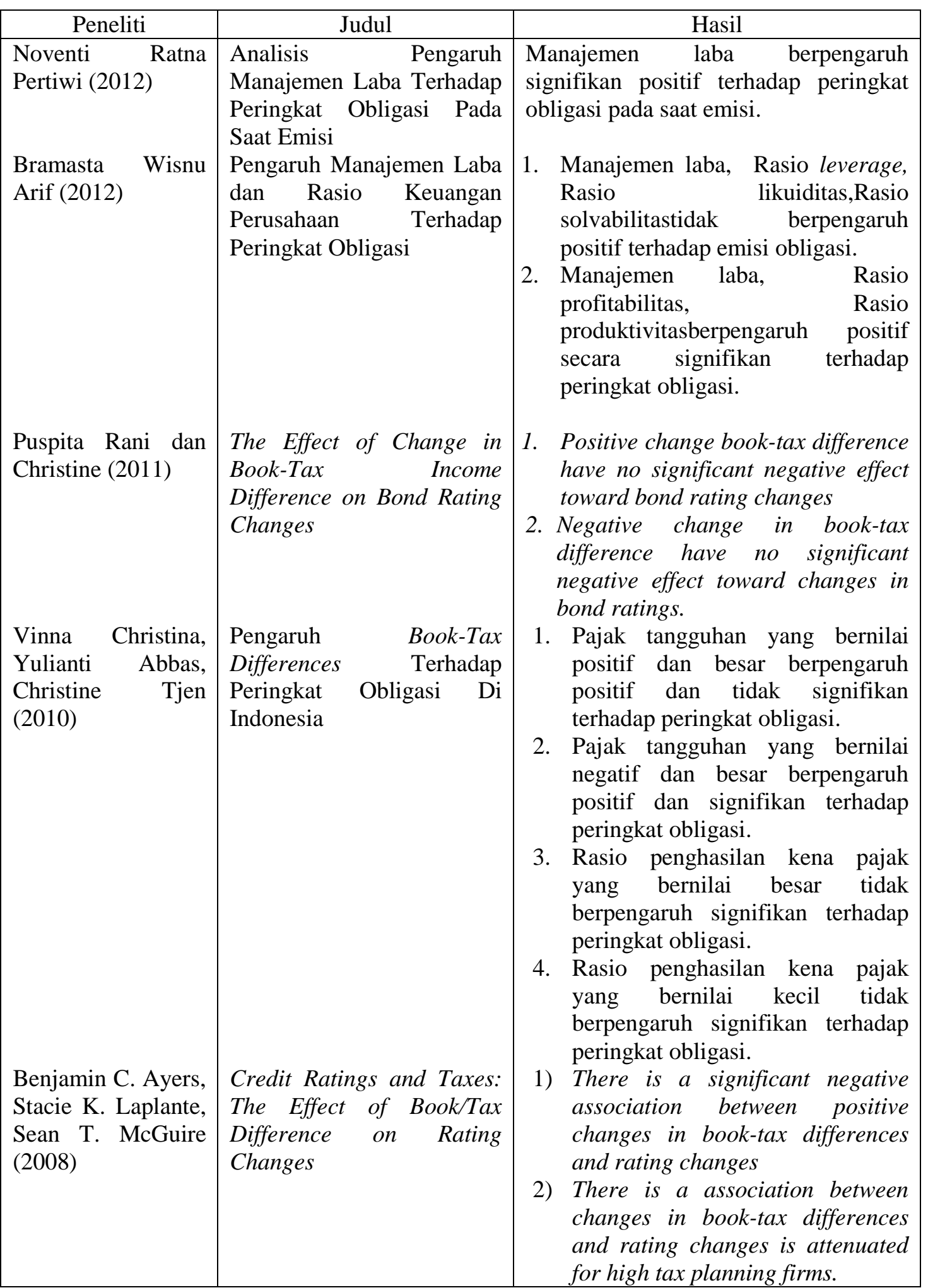


Model dalam penelitian ini menggunakan metode multiple regressions. Dalam penelitian ini ada dua variabel independen, yaitu manajemen laba dan perbedaan pembukuan menurut pajak dan akuntansi. Sedangkan, variabel dependen dalam penelitian ini yaitu peringkat obligasi.

Kerangka Konseptual

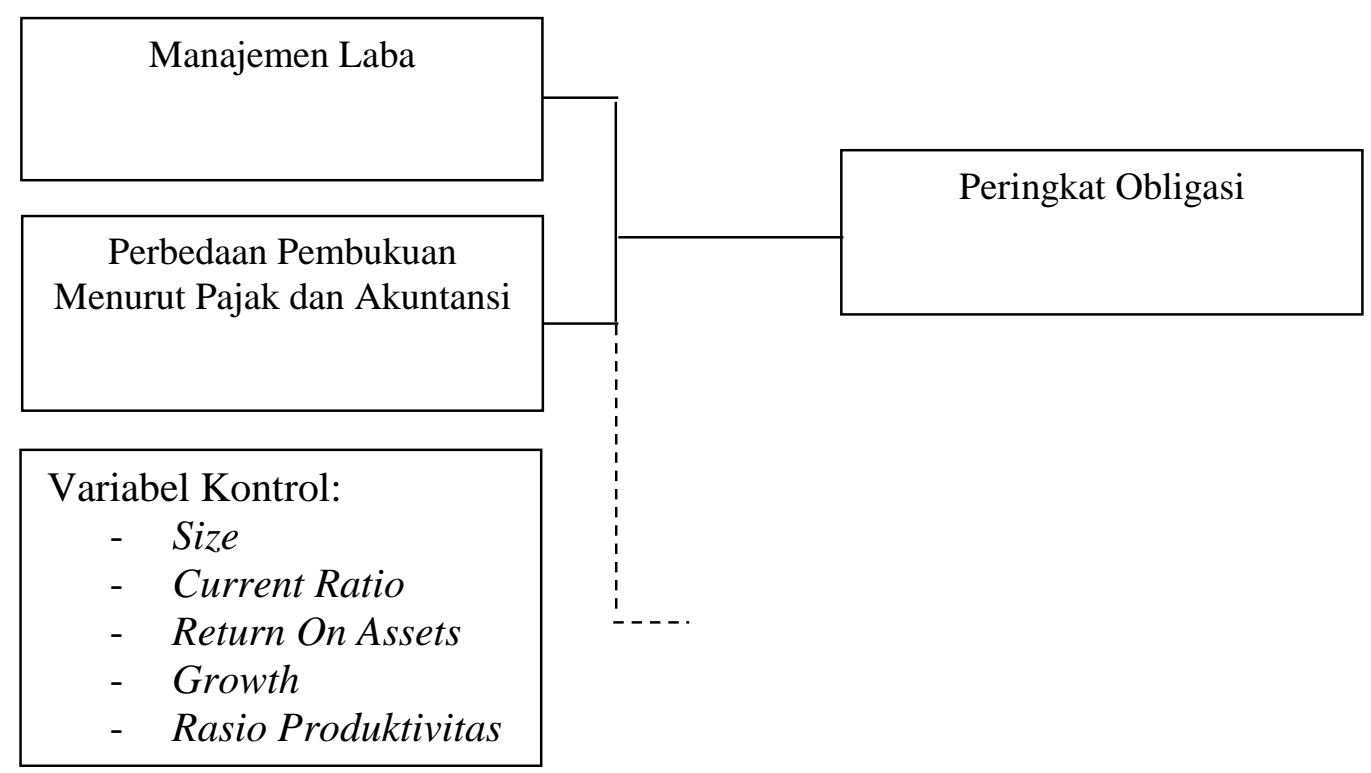

Gambar 2. Kerangka Pemikiran

Sumber: olahan penulis

Hipotesis. Berdasarkan landasan teori dan penelitian terdahulu di atas, maka hipotesis yang diajukan dalam penelitian ini sebagai berikut:

$\mathrm{H}_{1}$ : Pembukuan menurut pajak dan akuntansi berpengaruh negatif dan signifikan terhadap peringkat obligasi.

$\mathrm{H} 2$ : Manajemen laba berpengaruh positif dan signifikan terhadap peringkat obligasi.

H3: Manajemen laba dan perbedaan pembukuan menurut pajak dan akuntansi secara bersama-sama berpengaruh negatif dan signifikan terhadap peringkat obligasi.

\section{METODE}

Pemilihan Sampel. Populasi dalam penelitian ini yaitu semua jenis industri perusahaan, kecuali perusahaan di bidang banking, financing, dan insurance selama 4 tahun yang dimulai dari bulan Januari 2010 sampai Juni 2013, yang sudah go public dan terdaftar di Bursa Efek Indonesia (BEI). Sampel yang digunakan dalam penelitian ini yaitu purposive judgement sampling. Sampel-sampel yang akan dipilih harus sesuai dengan kriteria: (1) Bukan merupakan perusahaan pada bidang banking,financing, dan insurance, (2) Merupakan perusahaan penerbit obligasi (bukan sukuk) yang terdaftar di BEI sebelum tahun 2010, (3) Merupakan perusahaan yang menerbitkan obligasi empat tahun berturutturut, (4) Memiliki laporan keuangan triwulan dalam satuan mata uang Rupiah, (5) Sampel 
harus berdasarkan peringkat obligasi yang telah dinilai oleh PT PEFINDO setiap triwulannya.

Model Empiris Penelitian. Penelitian ini menggunakan data cross sectionaldan menggunakan lima variabel kontrol, yaitu: size, growth, current ratio, return on assets, dan produktivitas. Berikut adalah model yang digunakan dalam penelitian ini adalah:

$$
\begin{aligned}
\mathrm{PO}= & \alpha+\beta_{1} \mathrm{EM}+\beta_{2} \mathrm{BTD}+\beta_{3} \mathrm{ROA}+\beta_{4} \mathrm{CR}+\beta_{5} \mathrm{SIZE}+\beta_{6} \mathrm{GRO}+ \\
& \beta_{7} \mathrm{PROD}+\mathrm{e}
\end{aligned}
$$

Keterangan:

$\begin{array}{ll}\text { PO } & \text { = variabel dependen peringkat obligasi } \\ \text { EM } & \text { = variabel independen earnings management } \text { atau manajemen laba } \\ \text { BTD } & \text { = variabel independen book-tax difference } \\ \text { ROA } & \text { = variabel kontrol return on assets untuk mengukur profitabilitas } \\ \text { CR } & =\text { variabel kontrol current ratio untuk mengukur likuiditas } \\ \text { SIZE } & =\text { variabel kontrol size } \text { atau ukuran perusahaan } \\ \text { GRO } & =\text { variabel kontrol growth atau kenaikan pendapatan perusahaan } \\ \text { PROD } & =\text { variabel kontrol rasio produktivitas }\end{array}$

Variabel dependen.Variabel dependen dalam penelitian ini yaitu peringkat obligasi. Peringkat obligasi diukur berdasarkan peringkat yang diterbitkan oleh lembaga pemeringkat atau PT PEFINDO. Variabel ini diukur dengan menggunakan interpretasi Gu dan Zhao(2006) yang menggunakan kode 19 sampai dengan 1 (Tabel 2). Angka yang lebih besar merepresentasikan peringkat yang lebih tinggi.

Tabel 2. Kode Peringkat Obligasi

\begin{tabular}{cc}
\hline Peringkat Obligasi & Skala \\
\hline AAA & 19 \\
AA+ & 18 \\
AA & 17 \\
AA- & 16 \\
A+ & 15 \\
A & 14 \\
A- & 13 \\
BBB+ & 12 \\
BBB & 11 \\
BBB- & 10 \\
BB+ & 9 \\
BB & 8 \\
BB- & 7 \\
B+ & 6 \\
B & 5 \\
B- & 4 \\
CCC+ & 3 \\
CCC & 2 \\
CCC- & 1 \\
\hline
\end{tabular}

Sumber: Gu dan Zhao (2006) 
Variabel independen. Variabel independen yang digunakan dalam penelitian ini, yaitu: manajemen laba dan perbedaan pembukuan menurut pajak dan akuntasi.Variabel manajemen laba diukur dengan menggunakan discretionary revenue model Stubben (2010):

Dimana:

$$
\begin{aligned}
\Delta \mathrm{AR}_{\mathrm{it}}= & \alpha+\beta_{1} \Delta \mathrm{R}_{\mathrm{it}}+\beta_{2} \Delta \mathrm{R}_{\mathrm{it}} \times \mathrm{SIZE}_{\mathrm{it}}+\beta_{3} \Delta \mathrm{R}_{\mathrm{it}} \times \mathrm{AGE}_{\mathrm{it}}+\beta_{4} \Delta \mathrm{R}_{\mathrm{it}} \times \mathrm{AGE}_{-} \mathrm{SQ}_{\mathrm{it}}+ \\
& \beta_{5} \Delta \mathrm{R}_{\mathrm{it}} \times \mathrm{GRR} \mathrm{PR}_{\mathrm{it}}+\beta_{6} \Delta \mathrm{R}_{\mathrm{it}} \times \mathrm{GRR}_{-} \mathrm{N}_{\mathrm{it}}+\beta_{7} \Delta \mathrm{R}_{\mathrm{it}} \times \mathrm{GRM}_{\mathrm{it}}+\beta_{8} \Delta \mathrm{R}_{\mathrm{it}} \times \\
& \text { GRM_SQ } \mathrm{it}_{\mathrm{it}}+\text { it }
\end{aligned}
$$

$\Delta \mathrm{AR}_{\mathrm{it}}=$ piutang pada periode $\mathrm{t}$ dikurang dengan piutangperiode $\mathrm{t}-3$ kemudian dibagi dengan rata-rata total aset.

$\Delta \mathrm{R}_{\mathrm{it}}=$ pendapatan periode $\mathrm{t}$ dikurang dengan pendapatanperiode $\mathrm{t}-3$ kemudian dibagi dengan rata-rata total aset. Rata-rata total aset diperoleh dari aset pada periode $\mathrm{t}$ ditambah aset pada periode $\mathrm{t}-3$ dibagi dua.

SIZE = natural logaritma dari total aset perusahaan.

AGE = natural logaritma dari umur perusahaan.

AGE_SQ = AGE dikuadratkan.

GRM = laba kotor pada periode $\mathrm{t}$ dibagi dengan pendapatan pada periode $\mathrm{t}$.

GRM_SQ = GRM dikuadratkan.

GRR $=$ pendapatan periode $\mathrm{t}$ dikurang dengan pendapatanperiode $\mathrm{t}-3$ kemudian dibagi dengan pendapatan periode t-3. GRR terdiri dari GRR_P dan GRR_N. Jika GRR bernilai negatif maka GRR_P sama dengan 0 dan GRR_N bernilai 1, sedangkan jika GRR bernilai positif maka GRR_N sama dengan 0 dan GRR_P bernilai 1 .

Keterangan: $\mathrm{AR}=$ end of fiscal year accounts receivable; $\mathrm{R}=$ annual revenues; $\mathrm{SIZE}=$ natural log of total assets at end of fiscal year; $\mathrm{AGE}=$ age of firm (years); GRR = growth revenue at end of fiscal year; GRM = gross margin at end of fiscal year; _SQ = square of variable $;=$ annual change $; \mathrm{t}=$ triwulan.

Menurut Hanlon (2005) dalam Saputro (2011), book-tax differences merupakan perbedaan jumlah laba yang dihitung berdasarkan Pernyataan Standar Akuntansi Keuangan (PSAK) dengan peraturan perpajakan (UU No. 36 Tahun 2008). Variabel ini diukur dengan menggunakan rumus sebagai berikut:

Book-Tax Income Difference = Book Income - Taxable Income

Average Total Assets

Book Income diperoeh dari laba sebelum pajak dikurang dengan hak minoritas. Taxable Income diperoleh dari total beban pajak penghasilan dikurang dengan beban pajak penghasilan tangguhan kemudian dibagi dengan persentase pajak badan yaitu $25 \%$. Hasil perhitungan tersebut kemudian dikurang dengan perubahan pada total kerugian operasi bersih yang dapat dikompensasi (change on total net operating loss carry forward). Average total assets dihitung dengan menambahkan aset pada periode $\mathrm{t}$ dengan aset pada periode $\mathrm{t}-3$ kemudian dibagi dua.

Menurut Crabtree dan Maher (2009) dalam Christina, Yulianti, dan Christine (2010), jumlah book-tax difference yang besar dapat mengindikasikan adanya kualitas laba perusahaan yang rendah dan off-balance sheet financing, yang artinya ada kewajiban atau hutang perusahaan yang tidak diakui perusahaan dalam laporan keuangan. Hal ini 
menunjukkan bahwa laporan keuangan perusahaan tersebut telah memberikan informasi yang tidak akurat bagi pengguna laporan keuangannya sehingga lembaga peringkat dapat memberikan peringkat obligasi yang rendah terhadap perusahaan tersebut.

Variabel Kontrol. Ukuran Perusahaan/Size, ukuran perusahaan dihitung dengan natural logaritma dari total aset perusahaan. Rasio Produktivitas, digunakan untuk mengukur seberapa efektif suatu perusahaan dalam menggunakan sumber daya yang dimiliki perusahaanya. Rasio produktivitas ini dihitung dengan rumus penjualan dibagi total aset perusahaan. Rasio Likuiditas, diukur dengan menggunakan rasio lancar yang menunjukkan kemampuan perusahaan dalam memenuhi kewajibannya tepat pada waktunya. Rasio lancar (current ratio) ini dihitung dengan aset lancar dibagi hutang lancar. Profitabilitas, digunakan untuk mengukur kemampuan suatu perusahaan dalam menghasilkan laba dan untuk mengetahui efektivitas perusahaan dalam mengelola sumber daya yang dimilikinya. Penelitian ini menggunakan return on asset (ROA) sebagai proksi dari variabel profitabilitas. ROA dihitung dengan menggunakan rumus laba bersih dibagi dengan total aset. Growth, atau pertumbuhan suatu perusahaan diukur melalui rumus pendapatan pada periode $t$ dikurang pendapatan pada periode $\mathrm{t}-3$ dibagi pendapatan pada periode $\mathrm{t}-3$.

Metode Analisis Data. Metode pengolahan data yang digunakan dalam penelitian ini menggunakan uji statistik deskriptif melalui perhitungan mean, median, modus, persentase, perhitungan rata-rata dan uji asumsi klasik yang terdiri atas uji normalitas,uji heteroskedastisitas dan uji multikolinieritas. Dalam uji hipotesis akan diuji koefisien determinasi $\left(\mathrm{R}^{2}\right)$ digunakan untuk mengukur seberapa jauh kemampuan model dalam menjelaskan variabel terikatnya dan uji regresi simultan (Uji F) untuk mengetahui apakah semua variabel dependen yang terdapat dalam model penelitian secara bersama-sama berpengaruh terhadap variabel independennya atau tidak. Selain itu juga akan dilakukan uji regresi parsial (Uji t) untuk mengetahui seberapa jauh pengaruh variabel independen berpengaruh secara signifikan terhadap variabel dependen (Kuncoro, 2011).

\section{HASIL DAN PEMBAHASAN}

Deskripsi Objek Penelitian. Berdasarkan pemilihan sampel yang dilakukan dengan metode purposive sampling yang memiliki obligasi dari Januari 2010 sampai Juni 2013 secara berturut-turut yaitu 13 perusahaan. Adapun proses seleksi sampel berdasarkan kriteria yang telah ditetapkan adalah sebagai berikut:

Tabel 3. Pemilihan Sampel

\begin{tabular}{lc}
\hline \multicolumn{1}{c}{ Kriteria } & Jumlah \\
\hline Perusahaan yang memiliki obligasi tahun 2010-2013 & 195 \\
Perusahaan di bidang banking, finance, dan insurance & $(125)$ \\
Perusahaan yang tidak menerbitkan obligasi 5 tahun secara berturut- & $(52)$ \\
turut & \\
Perusahaan yang memiliki laporan keuangan dalam mata uang asing & $(3)$ \\
Perusahaan yang tidak memiliki laporan keuangan yang lengkap & $(1)$ \\
Perusahaan yang sudah tidak menjalankan kegiatan usaha & $(1)$ \\
Jumlah perusahaan yang digunakan sebagai sampel & 13 \\
Jumlah sampel akhir (firm quarter) & 182 \\
\hline
\end{tabular}


Statistik Deskriptif. Tabel 4 menunjukkan statistik deskriptif masing-masing variabel penelitian yang memberi gambaran mengenai karakteristik umum dari sampel meliputi nilai minimum, maximum, mean dan standar deviasi.

Deskripsi variabel: EM merupakan variabel independen.

Tabel 4. Statistik Deskriptif

\begin{tabular}{llrrrr}
\hline & N & Minimum & Maximum & \multicolumn{1}{c}{ Mean } & Std. Deviation \\
\hline EM & 182 &,- 03 &, 03 &, 000 &, 0125 \\
BTD & 182 &,- 1 &, 32 &, 104 &, 0901 \\
SIZE & 182 & 27,51 & 32,03 & 29,772 & 1,1302 \\
CR & 182 &, 27 & 2,61 & 1,425 &, 5476 \\
ROA & 182 &,- 09 &, 18 &, 04217 &, 03916 \\
PRODUKTIVITAS & 182 &,- 36 & 1,5 &, 558 &, 4241 \\
GROWTH & 182 & $-1,22$ & 1,89 &, 327 &, 7532 \\
PO & 182 & 11,98 & 18,77 & 15,374 & 1,6992 \\
Valid N (listwise) & 182 & & & & \\
\hline
\end{tabular}

Hasil analisis dengan menggunakan statistik deskriptif menunjukkan bahwa variabel independen earnings management (EM) dengan proksi discretionary revenue memiliki nilai minimum sebesar $-0,03$, nilai maksimum sebesar 0,03 , mean sebesar 0 , dan standar deviasi sebesar 0,0125. Hal ini dapat disimpulkan bahwa EM yang paling kecil dalam penelitian ini yaitu -0,03 dan EM yang paling besar yaitu 0,03. Rata-rata EM perusahaan menunjukkan nilai 0 berarti perusahaan-perusahaan yang menjadi sampel penelitian ini rata-rata tidak melakukan manajemen laba.

Untuk variabel perbedaan pembukuan antara pajak dan akuntansi atau Book-Tax Difference (BTD) dengan proksi book-tax income difference menunjukkan nilai minimum sebesar $-0,1$, nilai maksimum sebesar 0,32 , dan mean sebesar 0,104 , dan standar deviasi sebesar 0,0901. Hal ini dapat disimpulkan bahwa BTD paling rendah yaitu -0,1, perusahaan yang mempunyai BTD paling tinggi yaitu 0,32 , dan rata-rata BTD perusahaan dalam penelitian ini adalah 0,104 .

Hasil analisis dengan menggunakan statistik deskriptif terhadap variabel ukuran perusahaan (size) dengan proksi natural log dari total aset menunjukkan nilai minimum sebesar 27,51, nilai maksimum sebesar 32,03, mean sebesar 29,772, dan standar deviasi sebesar 1,1302. Hal ini dapat disimpulkan bahwa ukuran perusahaan paling kecil yaitu 27,51 , ukuran perusahaan yang paling besar yaitu 32,03, dan rata-rata ukuran perusahaan dalam penelitian ini adalah 29,772 .

Hasil analisis dengan menggunakan statistik deskriptif terhadap variabel current ratio (CR) dengan proksi current asset dibagi dengan current liabilities menunjukkan nilai minimum sebesar 0,27 , nilai maksimum sebesar 2,61, mean sebesar 1,425 , dan standar deviasi sebesar 0,5476. Hal ini dapat disimpulkan bahwa CR paling rendah yaitu 0,27, perusahaan yang mempunyai $\mathrm{CR}$ paling tinggi yaitu 2,61 , dan rata-rata $\mathrm{CR}$ perusahaan dalam penelitian ini adalah 1,425.

Pada bagian variabel return on asset dengan proksi laba bersih dibagi dengan total aset terlihat nilai minimum sebesar $-0,09$, nilai maksimum sebesar 0,18 , mean sebesar 0,04217, dan standar deviasi sebesar 0,03916. Hal ini dapat disimpulkan bahwa ROA 
paling rendah yaitu $-0,09$, perusahaan yang mempunyai ROA paling tinggi yaitu 0,18 , dan rata-rata ROA perusahaan dalam penelitian ini adalah 0,04217 .

Nilai variabel produktivitas dengan proksi sales dibagi dengan total aset menunjukkan nilai minimum sebesar $-0,36$, nilai maksimum sebesar 1,5 , mean sebesar 0,558 , dan standar deviasi sebesar 0,4241. Hal ini dapat disimpulkan bahwa produktivitas paling rendah yaitu $-0,36$, perusahaan yang mempunyai produktivitas paling tinggi yaitu 1,5, dan rata-rata produktivitas perusahaan dalam penelitian ini adalah 0,558.

Hasil analisis dengan menggunakan statistik deskriptif terhadap variabel growth dengan proksi revenue pada periode $\mathrm{t}$ dikurang revenue pada periode $\mathrm{t}-3$ kemudian dibagi revenue pada periode $\mathrm{t}-3$ menunjukkan nilai minimum sebesar $-1,22$, nilai maksimum sebesar 1,89, mean sebesar 0,327, dan standar deviasi sebesar 0,7532. Hal ini dapat disimpulkan bahwa growth paling rendah yaitu $-1,22$, growth yang paling tinggi yaitu 1,89 , dan rata-rata growth perusahaan dalam penelitian ini adalah 0,327 .

Hasil analisis dengan menggunakan statistik deskriptif terhadap variabel peringkat obligasi (PO) dengan proksi berupa pemberian kode pada setiap peringkat obligasi menunjukkan nilai minimum sebesar 11,98, nilai maksimum sebesar 18,77, mean sebesar 15,374, dan standar deviasi sebesar 1,6992. Hal ini dapat disimpulkan bahwa PO paling rendah yaitu 11,98 , perusahaan yang mempunyai PO paling tinggi yaitu 18,77 , dan ratarata $\mathrm{PO}$ perusahaan dalam penelitian ini adalah 15,374 .

\title{
Uji Normalitas
}

Tabel 5. Uji Normalitas: Kolmogorov-Smirnov Test

\begin{tabular}{|c|c|c|}
\hline \multicolumn{3}{|c|}{ One-Sample Kolmogorov-Smirnov Test } \\
\hline \multicolumn{3}{|c|}{ Unstandardized Residual } \\
\hline $\mathrm{N}$ & & 182 \\
\hline \multirow{2}{*}{ Normal Parameters ${ }^{\mathrm{a}, \mathrm{b}}$} & Mean &, 0000000 \\
\hline & Std. Deviation & 1,31089688 \\
\hline \multirow{3}{*}{$\begin{array}{l}\text { Most } \\
\text { Differences }\end{array}$} & Absolute & ,094 \\
\hline & Positive & ,094 \\
\hline & Negative &,- 078 \\
\hline \multicolumn{2}{|l|}{ Kolmogorov-Smirnov Z } & 1,265 \\
\hline \multicolumn{2}{|l|}{ Asymp. Sig. (2-tailed) } & 081 \\
\hline
\end{tabular}

Hasil pengujian menunjukkan bahwa data-data dalam penelitian telah berdistribusi normal karena nilai Asymp. Sig (2-tailed) data residual lebih besar dari tingkat signifikansi $\alpha=5 \%$.

\section{Uji Heteroskedastisitas}

\author{
Tabel 6. Uji White
}

Heteroskedasticity Test: White

\begin{tabular}{llll}
\hline F-statistic & 6.479036 & Prob. F(7,174) & 0.0000 \\
Obs*R-squared & 37.63013 & Prob. Chi-Square(7) & 0.0000 \\
Scaled explained SS & 50.18792 & Prob. Chi-Square(7) & 0.0000 \\
\hline
\end{tabular}


Uji heteroskedastisitas dilakukan dengan menggunakan uji white melalui Eviews versi 6. Hasil pengujian pada Tabel 6 menunjukkan adanya masalah heteroskedastisitas karena probability chi-square lebih rendah dari tingkat signifikansi $\alpha=5 \%$. Telah dilakukan treatment white heteroscedasticity untuk mengatasi masalah ini.

\section{Uji Multikolinieritas}

Tabel 7. Uji Multikolinieritas, Uji t

Coefficients $^{\mathrm{a}}$

\begin{tabular}{|c|c|c|c|c|c|c|}
\hline \multirow[t]{2}{*}{ Model } & \multicolumn{2}{|c|}{$\begin{array}{c}\text { Unstandardized } \\
\text { Coefficients }\end{array}$} & \multirow[t]{2}{*}{$\mathrm{t}$} & \multirow[t]{2}{*}{ Sig. } & \multicolumn{2}{|c|}{ Collinearity Statistics } \\
\hline & $\mathrm{B}$ & Std. Error & & & Tolerance & VIF \\
\hline (Constant) & $-10,383$ & 2,933 & $-3,541$ & ,001 & & \\
\hline EM & 1,957 & 8,059 & 243 & ,808 & ,974 & 1,027 \\
\hline BTD & 3,814 & 2,174 & 1,754 & 081 &, 257 & 3,890 \\
\hline SIZE &, 862 & ,096 & 8,961 & ,000 & ,836 & 1,196 \\
\hline $\mathrm{CR}$ & ,021 & ,204 & , 105 & ,917 & ,790 & 1,266 \\
\hline ROA & 2,556 & 5,164 & , 495 & ,621 & ,241 & 4,142 \\
\hline PRODUKTIVITAS &,- 756 & ,319 & $-2,368$ & 019 &, 538 & 1,858 \\
\hline GROWTH &,- 020 &, 142 &,- 138 & 890 & ,864 & 1,157 \\
\hline
\end{tabular}

a. Dependent Variable: PO

Berdasarkan Tabel 7, terlihat bahwa besarnya VIF dari tiap-tiap variabel kurang dari 10 dan Tolerance menunjukkan angka-angka di atas 0,10. Dapat disimpulkan bahwa penelitian ini bebas dari multikolinieritas.

\section{Uji Koefisien Determinasi $\left(\mathbf{R}^{2}\right)$}

Tabel 8. Koefisien Determinasi

\begin{tabular}{lrrrrr}
\multicolumn{7}{c}{ Model Summary $^{\mathbf{b}}$} & \\
\hline Model & $\mathrm{R}$ & R Square & \multicolumn{1}{c}{$\begin{array}{c}\text { Adjusted R } \\
\text { Square }\end{array}$} & $\begin{array}{l}\text { Std. Error of } \\
\text { the Estimate }\end{array}$ & \multicolumn{1}{c}{$\begin{array}{l}\text { Durbin- } \\
\text { Watson }\end{array}$} \\
\hline 1 &, $636^{\mathrm{a}}$ &, 405 &, 381 & 1,3370 &, 360 \\
\hline
\end{tabular}

Adjusted $\mathrm{R}^{2}$ yang dihasilkan dalam penelitian ini sebesar 0,381 atau $38,1 \%$ berarti variabel manajemen laba dan perbedaan pembukuan menurut pajak dan akuntansi dapat menjelaskan peringkat obligasi sebesar $38,1 \%$ dan sisanya $61,9 \%$ dijelaskan oleh variabelvariabel lain yang tidak diteliti dalam penelitian ini. Model penelitian ini cocok untuk digunakan karena nilai Adjusted $\mathrm{R}^{2}$ adalah positif.

Uji Hipotesis Parsial (Uji t). Hasiluji hipotesis ini dapat dilihat pada Tabel 7. Berdasarkan tabel tersebut, hasil hipotesis pengaruh perbedaan pembukuan menurut pajak dan akuntansi (BTD) terhadap peringkat obligasi (PO) menunjukkan p-value sebesar 0,081 dengan tingkat signifikansi $\alpha=10 \%$. Oleh karena $p$-value lebih kecil dari tingkat signifikasi $\alpha=10 \%$, maka dapat disimpulkan bahwa perbedaan pembukuan menurut pajak dan akuntansi berpengaruh signifikan terhadap peringkat obligasi. Hal ini berarti perbedaan pembukuan menurut pajak dan akuntansi berpengaruh signifikan terhadap 
peringkat obligasi dengan tingkat keyakinan 90\%. Hasil penelitian ini sesuai dengan penelitian Ayers et. al. (2008). Semakin besar selisih laba akuntansi dan laba menurut pajak, maka semakin tinggi peringkat obligasinya. Peneliti menduga hal ini terjadi karena sebagian besar sampel dalam penelitian ini memiliki BTD yang positif, berarti laba menurut akuntansi lebih besar daripada laba menurut pajaknya sehingga laporan keuangan komersil yang dilaporkan telah sesuai dengan kondisi keuangan perusahaan yang sebenarnya dan sesuai dengan PSAK yang berlaku.

Uji hipotesis kedua yaitu pengaruh manajemen laba (EM) terhadap peringkat obligasi menunjukkan $p$-value sebesar 0,808 dengan tingkat signifikasi $\alpha=10 \%$. Oleh karena $p$-value lebih besar daripada tingkat signifikasi $\alpha=10 \%$, maka dapat disimpulkan bahwa manajemen laba tidak berpengaruh signifikan terhadap peringkat obligasi. Hal ini diduga dikarenakan cara pengukuran yang berbeda dengan penelitian-penelitian yang sebelumnya. Pada penelitian ini digunakan discretionary revenue sebagai proksi dari manajemen laba, sedangkan penelitan lainnya menggunakan discretionary accruals sebagai proksinya

\section{Uji Simultan (Uji F)}

\begin{tabular}{|c|c|c|c|c|c|}
\hline \multicolumn{6}{|c|}{$0 \mathrm{J1}$} \\
\hline Model & $\begin{array}{l}\text { Sum of } \\
\text { Squares }\end{array}$ & df & Mean Square & $\mathrm{F}$ & Sig. \\
\hline Regression & 211,554 & 7 & 30,222 & 16,907 &, $000^{b}$ \\
\hline Residual & 311,040 & 174 & 1,788 & & \\
\hline Total & 522,593 & 181 & & & \\
\hline
\end{tabular}

Berdasarkan Tabel 9, terlihat bahwa Sig. yang dihasilkan yaitu 0,000 berarti dapat disimpulkan bahwa variabel perbedaan pembukuan menurut pajak dan akuntansi dan variabel manajemen laba secara bersama-sama berpengaruh terhadap peringkat obligasi karena nilai Sig lebih kecil dari tingkat signifikansi $\alpha=1 \%, 5 \%$ maupun $10 \%$.

\section{PENUTUP}

Simpulan. Hasil penelitian ini belum menemukan bukti adanya pengaruh manajemen laba yang diukur dengan discretionary revenue terhadap peringkat obligasi. Hasil penelitian ini bertentangan dengan penelitian Sari dan Bandi (2010) yang menemukan bukti bahwa manajemen laba berpengaruh positif dan signifikan terhadap peringkat obligasi. Perbedaan penelitian tersebut diperkirakan karena cara pengukuran yang berbeda. Untuk itu diperlukan penelitian selanjutnya dengan menggunakan beberapa model pengukuran manajemen laba. Sedangkan hasil untuk perbedaan pembukuan menurut pajak dan akuntansi yang diukur dengan book-tax income difference dengan peringkat obligasi menunjukkan hasil yang searah dengan penelitian Ayers et. al. (2008). Namun, pada penelitian ini pengaruh yang dihasilkan yaitu pengaruh positif berbeda dengan penelitian Ayers et. al. (2008) yang menghasilkan pengaruh negatif antara perbedaan pembukuan menurut pajak dan akuntansi dengan peringkat obligasi.

Saran. Untuk menguji konsistensi hasil penelitian, penelitian selanjutnya disarankan untuk menggunakan dua pengukuran manajemen laba yaitu model discretionary revenue menurut Stubben (2010)dan model discretionary accruals menurut Healy (1985) dan 
Modified-Jones (1991). Untuk pengukuran book-tax income difference, disarankan akan penelitian selanjutnya menggunakan model Weber (2008). Penelitian selanjutnya juga dapat menambahkan variabel-variabel lain yang terkait dengan faktor non akuntansi, seperti jaminan obligasi, umur obligasi, reputasi auditor, market value ratio, dan lain-lain. Penambahan variabel ini diharapkan agar hasil penelitian selanjutnya dapat lebih maksimal karena Adjusted $\mathrm{R}^{2}$ penelitian ini hanya $38,1 \%$, sedangkan $61,9 \%$ lainnya masih dipengaruhi oleh variabel lain yang tidak diteliti dalam penelitian ini.

\section{DAFTAR RUJUKAN}

Agoes, Sukrisno dan Estralita Trisnawati. (2012) Akuntansi Perpajakan. Edisi 2, Revisi. Jakarta: Salemba Empat.

Ayers, Benjamin C., Stacie K. Laplante dan Sean T. McGuire. (2008) "Credit Ratings and Taxes: The Effect of Book/Tax Differences on Obligation Ratings Changes." Contemporary Accounting Research 27, Vol. 2, pp. 359-402.

Badan Pengawas Pasar Modal, BAPEPAM Nomor V.C.2 Tentang Perizinan Perusahaan Pemeringkat Efek. Kep-151/BL/2009.

Christina, V., Yulianti dan Christine. (2010) "Pengaruh Book-Tax Differences Terhadap Peringkat Obligasi di Indonesia," Jurnal Akuntansi dan Keuangan Indonesia Vol. 7 (2).

Fahmi, Irham. (2013) Rahasia Saham dan Obligasi. Bandung: Penerbit Alfabeta.

$\mathrm{Gu}$, Z. dan J. Y. Zhao. (2006) "Accruals, Income Smoothing and Bond Rating". European Accounting Association Annual Congress and Seminar.

Herawaty, Vinola. (2008) "Peran Praktek Corporate Governance Sebagai Moderating Variable Dari Pengaruh Manajemen laba Terhadap Nilai Perusahaan”. Jurnal Akuntansi dan Keuangan, Vol. 10, (2) November 2008, pp. 97-108.

Ikatan Akuntan Indonesia. (2010) Standar Akuntansi Keuangan. Jakarta: Salemba Empat.

Kuncoro, Mudrajad. Prof., Ph.D. (2011) Metode Kuantitatif. Edisi Keempat. Yogyakarta: Unit Penerbit dan Percetakan Sekolah Tinngi Ilmu Manajemen YKPN.

Onji, Beby Dea Putri. (2013) "Pengaruh Faktor-faktor Akuntansi dan Non Akuntansi Dalam Mempengaruhi Peringkat Obligasi Pada Perusahaan Non Manufaktur yang Terdaftar di Bursa Efek Indonesia." Jurnal Universitas Putra Indonesia "YPTK" (2013). [e-journal] http://upi-yptk.ac.id/ejournal/File_Jurnal/jurnal\%20beby1.pdf (diakses pada tanggal 14 Oktober 2013).

Raharja \& Sari, M.P. (2008) "Kemampuan RasioKeuangan dalamMemprediksi Peringkat Obligasi(PT Kasnic Credit Rating)”. Jurnal Maksi, Vol. 8, (2), pp. 212-232.

Rani, P. dan Christine. (2011) "The Effect Of Change In Book-Tax Income Difference On Bond Rating Changes (Empirical Study Of Go Public Companies In Indonesia For The Period Of 2003-August 2010)" The 12 $2^{\text {th }}$ Asian Academic Accounting Association, 8-12 Oktober 2011, Bali-Indonesia.

Sari, S. R. K dan Bandi. (2010) "Praktik Manajemen Laba Terkait Peringkat Obligasi". Simposium Nasional Akuntansi XIII, Purwokerto 2010, pp 1-18.

Stubben, Stephen R. (2010) "Discretionary Revenue as a Measure of Earnings Management". The Accounting Review. Vol. 85, (2).

Sulistyanto. (2008) Manajemen Laba. Jakarta: Grasindo.

Sunariyah. (2004) Pengantar Pengetahuan Pasar Modal. UPP AMP YKPN. Yogyakarta. Undang-UndangNomor 36Tahun 2008TentangPajakPenghasilan. 
Weber, D. (2008) “Book-Tax Differences, Analysts' Forecast Errors, and Stock Returns". Working Paper, University of Connecticut.

Wijayanti. (2006) "Analisis Pengaruh Perbedaan Antara Laba Akuntansi dan Laba Fiskal Terhadap Persistensi Laba, Akrual, dan Arus Kas”. Simposium Nasional Akuntansi IX. 23-26 Agustus 2006, pp 1-31. 